\title{
Effect of Annealing Atomic Rearrangement on Electrochemical Performance of Pd-Ni Catalyst
}

\author{
Liquan Lu ${ }^{1, \#, *}$, Shaofeng $\mathrm{Yu}^{2, \#}$, Xiuping Yue ${ }^{2}$, Jing Wang ${ }^{1}$, Meisheng Liang ${ }^{2}$, Lizhen Gao ${ }^{2}$, \\ Shaohui Yan ${ }^{2, *}$ \\ ${ }^{1}$ College of Mechatronic Engineering, North University of China, Taiyuan 030051, China \\ ${ }^{2}$ College of Environmental Science and Engineering, Taiyuan University of Technology, Taiyuan, \\ 030024, China \\ \# The first two authors contributed equally to this paper. \\ *E-mail: lq_lu@buaa.edu.cn; yanshaohui@tyut.edu.cn
}

doi: $10.20964 / 2020.08 .90$

Received: 5 April 2020/ Accepted: 6 June 2020 / Published: 10 July 2020

The rearrangement of the $\mathrm{Pd}$ and $\mathrm{Ni}$ atoms in the $\mathrm{Pd}-\mathrm{Ni}$ nanoparticles is achieved by annealing under a vacuum condition with an absolute pressure of $0.03 \mathrm{MPa}$, to successfully synthesize carbon supported composite nanoparticles with $\mathrm{Pd}$ core and $\mathrm{NiO}_{\mathrm{x}} \mathrm{H}_{\mathrm{y}}$ doped $\mathrm{PdO}$ shell $\left(\mathrm{Pd} @ \mathrm{PdO}-\mathrm{NiO}_{\mathrm{x}} \mathrm{H}_{\mathrm{y}} / \mathrm{C}\right)$. This unique structure with a $\mathrm{Pd}$ core and a $\mathrm{PdO}$ metal oxide shell doped by $\mathrm{NiO}_{\mathrm{x}} \mathrm{H}_{\mathrm{y}}$ is proved by the $\mathrm{X}$-ray diffraction analysis and energy dispersive spectrometer mapping images. The shell structure of the $\mathrm{Pd} @ \mathrm{PdO}-\mathrm{NiO}_{\mathrm{x}} \mathrm{H}_{\mathrm{y}}$ nanoparticles is further proved by the $\mathrm{X}$-ray photoelectron spectroscopy. The electrochemical test results indicate that the core-shell catalyst prepared at $400{ }^{\circ} \mathrm{C}(\mathrm{Pd} @ \mathrm{PdO}-$ $\mathrm{NiO}_{\mathrm{x}} \mathrm{H}_{\mathrm{y}} / \mathrm{C}-400$ ) catalyst has the best catalytic activities and stabilities in all the catalysts for the methanol electro-oxidation (MEO) and ethanol electro-oxidation (EEO). The peak value of the mass specific current density on the $\mathrm{Pd} @ \mathrm{PdO}-\mathrm{NiO}_{\mathrm{x}} \mathrm{H}_{\mathrm{y}} / \mathrm{C}-400$ catalyst for the $\mathrm{MEO}$ reaches to $1118.9 \mathrm{~mA}$ $\mathrm{mg}^{-1} \mathrm{Pd}$, which is 2.5 and 1.4 times those of the $\mathrm{Pd} / \mathrm{C}\left(443.1 \mathrm{~mA} \mathrm{mg}^{-1} \mathrm{Pd}\right)$ and $\mathrm{Pd}-\mathrm{Ni} / \mathrm{C}\left(828.1 \mathrm{~mA} \mathrm{mg}^{-1}\right.$ $\mathrm{Pd}$ ) catalysts, respectively. This improvement is attributed to the unique doped structure between $\mathrm{NiO}_{\mathrm{x}} \mathrm{H}_{\mathrm{y}}$ and $\mathrm{PdO}$ in the shell layer of the Pd-based nanoparticles in the core-shell catalyst, the promoting effect of the $\mathrm{NiOOH}$, as well as the bifunctional mechanism. Under the influence of this doped structure, the new Pd nanoparticles generated by the rearrangement of the Pd atoms in the electrochemical activation process, are divided by the $\mathrm{NiO}_{\mathrm{x}} \mathrm{H}_{\mathrm{y}}$ species, resulting in the new formed $\mathrm{Pd}$ nanoparticles have ultra-small size and high stability. These are also the reason that the Pd@PdO$\mathrm{NiO}_{\mathrm{x}} \mathrm{H}_{\mathrm{y}} / \mathrm{C}-400$ catalyst reveals good durability for both the MEO and EEO. Moreover, the ratio between its stable current densities for the $\mathrm{EEO}\left(86.35 \mathrm{~mA} \mathrm{mg}{ }^{-1} \mathrm{Pd}\right)$ and $\mathrm{MEO}\left(12.57 \mathrm{~mA} \mathrm{mg}^{-1} \mathrm{Pd}\right)$ after $3600 \mathrm{~s}$ at $-0.1 \mathrm{~V}$ vs. $\mathrm{Ag} \mid \mathrm{AgCl}$ is 6.9 , showing that the $\mathrm{Pd} @ \mathrm{PdO}-\mathrm{NiO}_{\mathrm{x}} \mathrm{H}_{\mathrm{y}} / \mathrm{C}$ catalyst has broad application prospects in the field of the direct ethanol fuel cells.

Keywords: Direct Alcohol Fuel Cells; Methanol Electro-oxidation; Ethanol Electro-oxidation; Coreshell Structure; $\mathrm{Pd}$ based nanocatalyst; $\mathrm{NiO}_{\mathrm{x}} \mathrm{H}_{\mathrm{y}}$ doped $\mathrm{PdO}$. 


\section{FULL TEXT}

(C) 2020 The Authors. Published by ESG (www.electrochemsci.org). This article is an open access article distributed under the terms and conditions of the Creative Commons Attribution license (http://creativecommons.org/licenses/by/4.0/). 